\title{
Implementasi Jaringan Internet Sehat Pada UPTD. Puskesmas Trimulyo Lampung Timur
}

\author{
Arif Hidayat, S.T., M.Kom ${ }^{1}$ ), Lilik Joko S., M.T.I ${ }^{2}$ ) \\ ${ }^{1,2)}$ Program Studi Ilmu Komputer, Fakultas Ilmu Komputer, Universitas Muhammadiyah Metro \\ J1. Gatot Subroto No.100, Yosodadi, Metro Timur, Kota Metro, Lampung, Indonesia 34381 \\ Email : androidarifhidayat@gmail.com ${ }^{1}$, lilikjoko09@gmail.com²
}

\begin{abstract}
ABSTRAK
Saat ini kondisi jaringan internet pada UPTD Puskemas Trimulyo Lampung Timur sudah cukup baik dalam pembatasan akses internet, tetapi masih memiliki adanya kekurangan yaitu dalam pengontrolan akses situs bergantung pada internet Sehat ISP Telkom speedy sehingga jaringan internet pada instansi tersebut masih tergolong bebas mengakses ke situs manapun. Tujuan penelitian ini ialah menganalisis dan merancang sebuah sistem yang akan membatasi hak pengguna dalam mengakses website-website pada jaringan internet di UPTD Puskemas Trimulyo Lampung Timur. Oleh karena itu Peneliti ingin ikut berpartisipasi dalam mengontrol konten yang diakses melalui jaringan internet UPTD Puskemas Trimulyo Lampung Timur. Penelitian ini menggunakan metode berupa pengamatan, wawancara, dokumentasi dan studi pustaka. Sedangkan perancangan layout jaringan menggunakan topologi star dan untuk pemblokiran situs menggunakan proxy squid. Software pendukung dalam pembuatan jaringan komputer menggunakan Oracle Virtualbox 4.2.4 dan OS Debian 6. Kesimpulan dari penelitian ini adalah telah membangun jaringan internet Sehat menggunakan topologi star pada UPTD Puskemas Trimulyo Lampung Timur serta telah dihasilkannya penerapan jaringan internet Sehat menggunakan Debian 6 yang berfungsi untuk memblokir situs berkonten Pornografi, SARA, perjudian serta sejenisnya.
\end{abstract}

Kata Kunci - Content Filtering, Internet Sehat, Proxy Server, Squid.

\section{Pendahuluan}

Teknologi informasi dan komunikasi saat ini telah menjadi satu hal yang sangat penting bagi kehidupan manusia. Di antara teknologi ini yang banyak digunakan saat ini adalah internet. Internet merupakan sebuah jaringan komunikasi dan informasi global. Disini ada banyak manfaat dengan leluasa bisa kita dapatkan baik data atau informasi untuk membantu pekerjaan, membaca berita nasional maupun manca negara, mencari lowongan pekerjaan ataupun beasiswa, bahkan termasuk sumber berbagai ilmu. Tentu saja tidak seluruh isi internet dapat bermanfaat, jika kita tak pandai dalam menggunakan internet. Karena sifatnya yang cenderung bebas tanpa kontrol pihak manapun, maka ada saja materi atau isi yang bersifat negatif di internet ataupun yang dikirim/terkirim melalui internet. Internet Sehat berfungsi untuk mencegah atau membatasi pengguna, melihat dan mengunjungi situs - situs yang dianggap mengandung salah satu unsur berbahaya atau terlarang seperti judi dan pornografi, meminimalisir terinfeksinya PC dan laptop dari aneka macam program jahat (virus, worm, trojan horse, spyware, adware). Meski berbeda dengan media informasi lainnya, internet memiliki aturan "Baku" yang efektif untuk meminimalisir prilaku negatif. Kondisi jaringan internet pada UPTD Puskemas Trimulyo Lampung Timur saat ini sudah cukup baik dalam pembatasan akses internet, tapi masih memiliki adanya kekurangan yaitu dalam pengontrolan akses situs bergantung pada Internet Service Provider (ISP) Telkom speedy sehingga jaringan internet masih tergolong bebas mengakses ke situs manapun. Hal tersebut akan berdampak buruk bagi PC, Laptop dan pengguna fasilitas jaringan internet, seperti terinfeksi virus berbahaya seperti Trojan horse, ransomeware atau konten yang mengandung pornografi dan perjudian. Maka dari itu Peneliti ingin ikut berpartisipasi dalam mengontrol konten yang diakses melalui jaringan UPTD Puskemas Trimulyo Lampung Timur.

Rumusan masalah yang terjadi adalah bagaimana merancang jaringan Internet Sehat menggunakan Debian 6 pada UPT Puskesmas Trimulyo Kecamatan Sekampung Kabupaten Lampung Timur serta bagaimana memblokir situs berkonten negatif yang dikonfigurasi menggunakan Proxy Squid.

Ruang lingkup penelitian ini meliputi perancangan topologi baru yang dilengkapi dengan perangkat proxy Squid dan melakukan konfigurasi content filtering sebagai fitur dari Proxy Squid. 


\section{Jurnal Ilmu Komputer \& Iniormatika JKI}

2. Tinjauan Pusaka

Untuk membantu penelitian ini, maka digunakan beberapa teori yang terkait, yaitu:

\section{A. Linux Debian}

Linux Debian merupkan sistem operasi berbasis open source yang di kembangkan secara terbuka oleh banyak programer sukarelawan yang ingin mengembakan debian. Sistem operasi debian adalah gabungan dari perangkat lunak yang dikembangkan dengan lisensi GNU, dan utamanya menggunakan kernel linux. Sistem operasi ini yang mengunakan kernel linux yang merupakan salah satu distro linux yang populer dengan kesetabilannya.

\section{B. Proxy Server}

Server merupakan sebuah komputer yang menyediakan layanan untuk komputer lain. Salah satu server yang sering digunakan adalah proxy. Proxy server merupakan sebuah server yang berfungsi sebagai perantara antara komputer klien dengan server lain. Hal ini menyebabkan semua request yang datang dari LAN atau komputer klien akan akan masuk ke dalam proxy server kemudian proxy server akan meneruskan request tersebut ke target server. Proses tersebut juga terjadi ketika adanya reply dari target server ke komputer klien. Tugas dari proxy server ini yaitu untuk memilih request yang dilakukan berdasarkan aturan-aturan yang dibuat dan mengizinkan proses komunikasi terjadi apabila request tersebut tidak melanggar aturan tersebut. Aturan-aturan ini biasanya berdasarkan alamat IP klien atau pun target server, protokol, dan web content.

\section{Topologi Star}

Topologi ini membentuk seperti bintang Karena semua komputer dihubungkan ke sebuah hub atau switch dengan kabel UTP, sehingga hub/switch lah pusat dari jaringan dan bertugas untuk mengontrol lalu lintas data, jadi jika komputer 1 ingin mengirim ke komputer 4, tujuan tanpa melewati komputer lain. Topologi jaringan inilah yang paling banyak digunakan sekarang Karena kelebihannya lebih banyak. Kelebihannya yaitu mudah mendeteksi komputer yang mengalami gannguan, mudah untuk melakukan update komputer. Sedangkan kekurangannya topologi ini memerlukan biaya yang tinggi untuk pemasangan, Karena membutuhkan kabel yang banyak serta hub dan kestabilan jaringan sangan tergantung pada terminal pusat, sehingga jika hub mengalami gangguan maka seluruh jaringan akan terganggu.

\section{Dynamic Host Configuration Protocol (DHCP)}

DHCP merupakan salah satu protokol yang termasuk dalam internet layer pada jaringan TCP/IP. Protokol ini umum digunakan oleh network administrator untuk memberikan IP address pada komputer klien secara otomatis. Informasi yang diberikan tidak hanya terbatas pada IP Address saja,
Vol. 1, No. 1, Juli 2020

DNS server, default gateway, subnet mask merupakan contoh lain dari informasi yang dapat dikonfigurasi menggunakan DHCP. DHCP menggunakan model client-server, DHCP server bertugas sebagai penyedia informasi yang dibutuhkan, sedangkan DHCP client meminta informasi yang dibutuhkan.

Ada 4 cara mengenai pengalokasian alamat ini, yaitu static allocation, dynamic allocation, automatic allocation, dan hybrid allocation (Droms dan Lemon, 2003:15). Dengan static allocation, DHCP server menyimpan informasi yang identik (misalkan MAC address) dengan komputer klien dan network administrator akan mengalokasikan alamat yang statis berdasarkan informasi yang dimiliki tersebut. Sedangkan Dynamic allocation merupakan pengalokasian alamat kepada komputer klien secara otomatis berdasarkan alamat yang ada dalam pool (berisikan alamat-alamat yang dapat diberikan kepada klien) dalam jangka waktu tertentu. Pada Automatic allocation memiliki metode yang hampir sama dengan dynamic allocation, perbedaannya adalah dalam metode automatic allocation alamat diberikan secara permanen. Untuk hybrid allocation, network administrator akan membuat daftar klienklien yang diperbolehkan untuk mendapatkan alamat dari DHCP server tanpa mengalokasikan alamatnya secara statis.

\section{Metode Penelitian}

Metode yang dilakukan dalam penelitian ini terdiri dari:

1. Studi Kepustakaan

Studi kepustakaan ini terkait dengan pencarian literatur ataupun referensi yang berhubungan dengan topik yang dibahas dalam penelitian ini, sehingga penelitian yang dilakukan sesuai dengan teori yang ada.

2. Pencarian Fakta

Dalam mencari data dan fakta yang dibutuhkan, penelitian ini menggunakan beberapa teknik, yaitu:

a. Teknik Wawancara

Wawancara merupakan teknik umum yang biasa dilakukan untuk mendapatkan informasi yang dibutuhkan. Wawancara adalah teknik mengumpulkan informasi dari individu yang bersangkutan dengan melakukan tatap muka secara langsung kepada narasumber. Penelitian ini melakukan wawancara kepada Pimpinan UPTD Puskemas Trimulyo Kecamatan Sekampung Kabpuaten Lampung Timur.

b. Teknik Observasi

Observasi adalah teknik pencarian fakta atau informasi dengan melakukan studi, mengamati, dan menganalisis objek secara langsung. Teknik ini digunakan dalam penelitian untuk menganalisis jaringan yang 


\section{Jurnal IImu Komputer \& Informatika JIKI}

sedang berjalan dan merancang topologi baru yang dibahas dalam penelitian ini.

\section{HASIL DAN PEMBAHASAN}

Pada tahapan menghasilkan hasil pemaparan dan analisa peneliti yang dijelaskan dengan alur konfigurasi server pada Gambar 1.

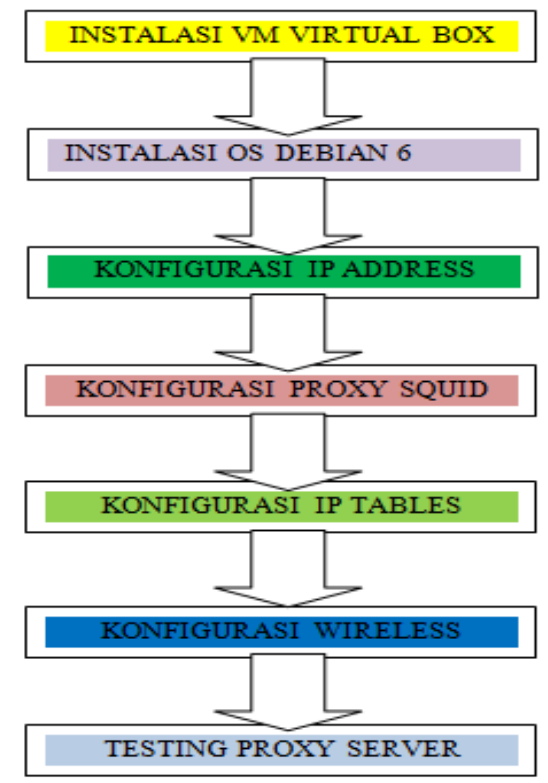

Gambar 1. Alur Konfigurasi Server

\section{A. Instalasi Virtual Box}

Peneliti menggunakan Virtual Box versi 4.2.4.

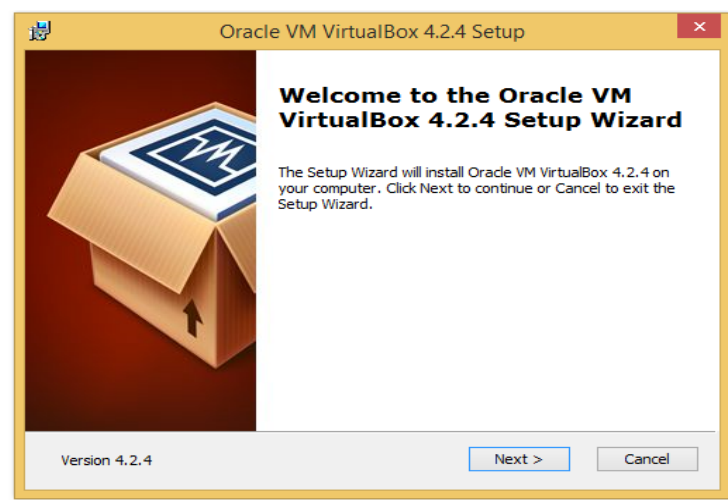

Gambar 2. Tampilan Instalasi App Virtualbox

\section{B. Instalasi OS Debian}

Peneliti menggunakan Operating System Debian versi 6.
Vol. 1, No. 1, Juli 2020

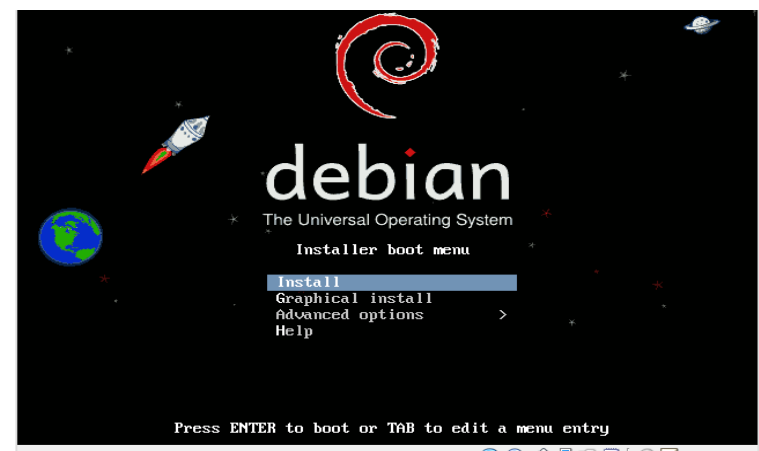

Gambar 3. Memulai Instalasi Debian 6

\section{Konfigurasi IP Address}

Login dengan user: admin yang sebelumnya dibuat saat proses instalasi dan masukkan passwordnya, kemudian masuk sebagai Super User (su). Kemudian edit file /etc/network/interface.

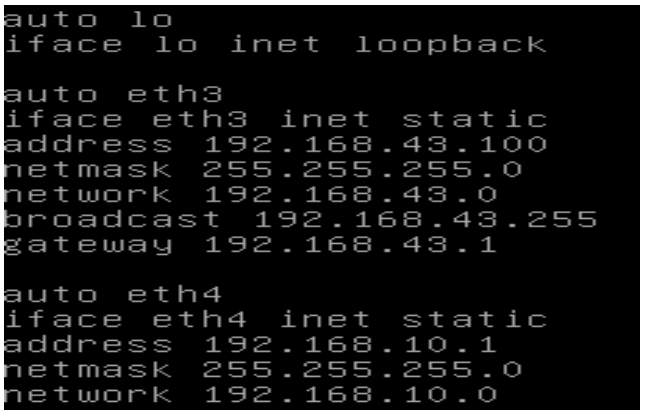

Gambar 4. Konfigurasi IP Address

\section{Konfigurasi Proxy Squid}

Acl jaringan yaitu Mendefinisikan acl untuk jaringan yang akan kita control hak aksesnya. http_access allow jaringan maksudnya adalah memberikan hak akses http untuk acl jaringan. Sedangkan acl situsdilarang adalah penempatan situs yang akan di blokir melalui squid. Selain itu Cari Http_port, dan tambahkan kata Transparent supaya tidak perlu mensetting proxy untuk pemblokiran situs pada browser ketika berselancar di internet. Serta rubah visible_hostname, yaitu mendefinisikan nama computer untuk server proxy dan Kemudian cari cache_mgr yaitu untuk menentukan email administrator dan hilangkan tanda kressnya.

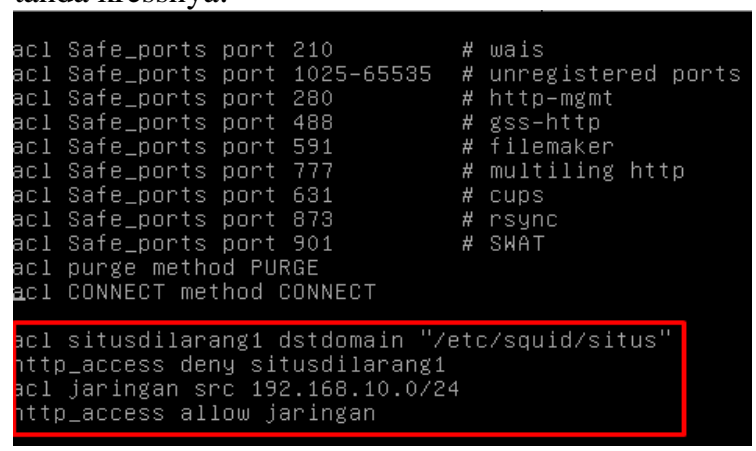

Gambar 5. Konfigurasi Proxy Squid 


\section{Jurnal Ilmu Komputer \& Iniormatíka JIKI}

Kemudian edit file situs yang berisikan domain yg akan di filter sesuai dengan lokasi direktori yang di setting pada squid.conf. Masukkkan beberapa domain yang akan difilter.

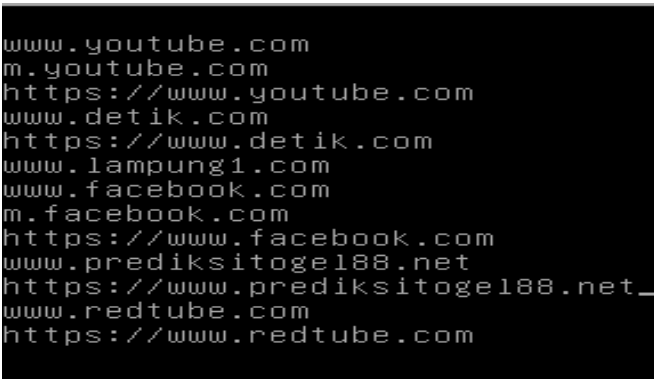

Gambar 6. List Domain yang Diblokir

E. Konfigurasi IP Tables

Untuk blokir situs https, tambahkan syntax pada file letc/rc.local untuk mengalihkan paket menuju port 80 dan 443 (browsing) yang masuk ke eth3 yang berasal dari network 192.168.8.0/24 menuju proxy server yaitu 3128 dan port 65535 untuk port pribadi. Berikut ini adalah script untuk blokir https: iptables -I FORWARD - p tcp --dport 80 -m string string 'facebook.com'--algo bm --to 65535 -j DROP iptables -I FORWARD -p tcp --dport 443 -m string -string 'facebook.com'--algo bm --to 65535 -j DROP iptables -I FORWARD - p tcp --dport 80 -m string -string 'detik.com'--algo bm --to 65535 -j DROP iptables -I FORWARD -p tcp --dport 443 -m string -string 'detik.com'--algo bm --to 65535 -j DROP iptables -I FORWARD -p tcp --dport 443 -m string -string 'redtube.com'--algo bm --to 65535 -j DROP

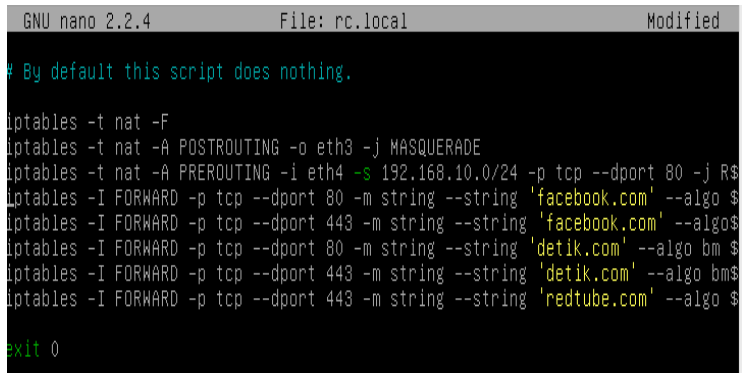

Gambar 7. Konfigurasi Iptables untuk https

\section{F. Konfigurasi $\mathrm{DHCP}$ pada Wireless}

Konfigurasi $D H C P$ ini dilakukan untuk membatasi penggunaan perangkat yang digunakan untuk mengakses jaringan internet.

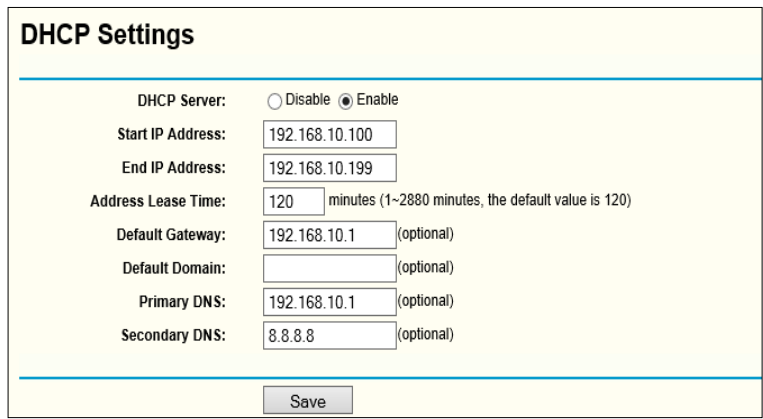

Vol. 1, No. 1, Juli 2020

\section{Gambar 8. Konfigurasi DHCP pada Wireless}

\section{G. Pengujian Proxy Server}

Akses domain pornografi misalkan www.redtube.com, maka akan domain tersebut diblokir oleh proxy squid/ proxy server (tidak diizinkan di akses).

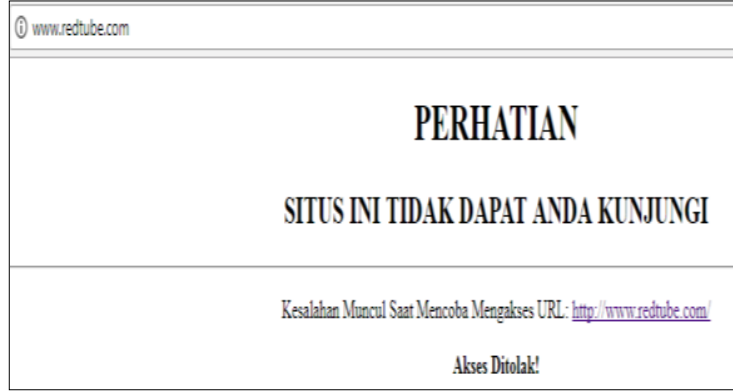

\section{Gambar 9. Pengujian Sukses Blokir Situs} Berkonten Pornografi

\section{KESIMPULAN}

Adapun kesimpulan dalam penelitian ini yaitu:

[1] Dihasilkan penerapan atau implementasi proxy squid pada jaringan internet pada UPTD Puskemas Trimulyo Lampung Timur dengan OS Server Debian 6

[2] Design dan konfigurasi internet Sehat menggunakan Debian 6 pada UPTD. Puskemas Trimulyo Lampung Timur dirancang menggunakan Topologi Star.

[3] Telah berhasil melakukan pengujian implementasi internet sehat dengan menutup akses situs-situs yang berkonten negative seperti sara, judi pornografi. Selain itu pengujian pada penelitian ini juga berhasil melakukan block port https.

\section{Daftar Pustaka}

[1] Winarno dan Smitdev, 2014, Membuat Jaringan Komputer di Windows dan Linux, PT Elex Media Komputindo, Jakarta.

[2] Bruno, A., Jordan, S. (2011). CCDA 640-864 Official Cert Guide. Indianapolis: Cisco Press

[3] Droms, R., Lemon,T. (2003). The DHCP Handbook. Second Edition. Indianapolis: Sams

[4] Hidayat, A. (2016). Implementasi Control Panel Hosting dengan VestaCP pada Server Intranet LAB Multimedia D-III Manajemen Informatika UM Metro. MIKROTIK: Jurnal Manajemen Informatika, 6(2).

[5] Jeffries, Amos. 2013. SquidFaq/SquidAcl Squid Web Proxy Wiki. Retrieved (01-28-2014) from cache.org/SquidFaq/SquidAcl http://wiki.squid-

[6] Johansson, P., Kapoor, R., Kazantzidis, M., \& Gerla, M. (2002). Personal Area Networks: Bluetooth Or IEEE 802.11. International Journal of Wireless Information Networks, 9 (2), 89-103. 
[7] Odom, W. (2008). CCENT/CCNA ICNDI Official Exam Cert Guide. Second Edition. Indianapolis: Cisco Press.

[8] Laudon, Kenneth C., Laudon, Jane P. (2012). Management Information Systems Managing The Digital Firm. New Jersey: Pearson Education.

[9] Odom, W. (2004). Computer Networking firststep. Indianapolis: Cisco Press.

[10] Pavani, V., Chandrika, I. L. V., \& Krishna, A. R. (2012). Local Area Network (LAN) Technologies. International Journal of Innovative Technology and Exploring Engineering, 1 (6), 70-73.

[11] Saini, K. (2011). Squid Proxy Server 3.1 Beginner's Guide. Birmingham: Packt Publishing.

[12] Saxena, S. (2013). Content Filtering Using Internet Proxy Servers. International Journal of Computer \& Organization Trends, 3 (2), 10-15.

[13] Tanenbaum, A., Wetherall, D. J. (2011). Computer Networks. Fifth Edition. Boston: Pearson Education.

[14] Wessels, D. (2004). Squid: The Definitive Guide. California: O'Reilly Media

[15] Hartono, Jogiyanto, 1999, Pengenalan Komputer, Andi Offset, Yogyakarta

[16] Hidayat, Arif, 2016, Panduan BelajarMandiri Administrasi Server Jaringan Menggunakan Linux Ubuntu, Laduny, Metro

[17] Komputer, Wahana, 2013, Internet Aman \&Sehat, Andi Offset, Yogyakarta

[18] Ladjamudin, Al Bahra, 2005, Analisis dan Desain Informasi, Graha Ilmu, Yogyakarta,

[19] Sinarmata, Janner, 2006, Teknologi Komputer dan Informasi, Andi Offset, Yogyakarta

[20] Hidayat, A. (2017). Konfigurasi Server Cloud Storage pada Jaringan LAN pada LAB Diploma III Manajemen Informatika UM Metro. MIKROTIK: Jurnal Manajemen Informatika, $7(1)$. 